\title{
Empowerment of wirid group (study of mothers) through fish nugget processing utilizing fish potential in Haranggaol Sub-District Haranggaol Horison District, Simalungun Regency
}

\author{
Fajar Utama Ritonga ${ }^{1 *}$, Husni Thamrin ${ }^{1}$, Agus Suriadi ${ }^{1}$, Berlianti $^{1}$ \\ ${ }^{1}$ Faculty of Social Science and Political Science, Universitas Sumatera Utara, Medan \\ *Email: fajar.utama@usu.ac.id
}

\begin{abstract}
Great potential as a producer of Goldfish and Tilapia in the Haranggaol Village is very large, and the production of fish is very well known up to the city of Medan, each Goldfish buyer knows the quality of Goldfish originating from the Haranggaol Region and has a relatively high price (above average) (average price of goldfish from other regions), but the fish production can be developed further from economic value if obtained in other forms such as fish processing into fish nuggets which are still rarely carried out by the local community, by looking at the potential quantity and quality of fish in Haranggaol Village. used as a potential source of Social Welfare for the community, especially the wamad mamak (recitation of mothers) group who routinely conduct recitation in the Haranggaol Village.
\end{abstract}

Keyword: Fish, Fish Production, Haranggaol Village

\begin{abstract}
Abstrak
Potensi besar sebagai penghasil Ikan Mas dan Ikan Nila di Kelurahan Haranggaol sangat besar, dan produksi ikan tersebut sudah sangat terkenal sampai ke Kota Medan, setiap pembeli Ikan Mas mengetahui kualitas Ikan Mas yang berasal dari Daerah haranggaol serta memiliki harga yang relatif tinggi (di atas rata-rata harga Ikan Mas dari daerah lainnya), namun produksi ikan tersebut dapat dikembangkan lagi dari nilai ekonomis jika dioleh dalam bentuk lain seperti pengolahan ikan menjadi Nugget ikan yang masih jarang dilakukan oleh masyarakat setempat, dengan melihat potensi kuantitas dan kualitas ikan di Kelurahan Haranggaol dapat dijadikan sumber potensi Kesejahteraan Sosial bagi masyarakat khususnya kelompok wirid mamak-mamak (pengajian ibu-ibu) yang rutin melakukan pengajian di Kelurahan Haranggaol.
\end{abstract}

Kata Kunci : Ikan, Produkai Ikan, Desa Haranggaol

\section{PENDAhuluan}

Potensi besar sebagai penghasil Ikan Mas dan Ikan Nila di Kelurahan Haranggaol sangat besar, dan produksi ikan tersebut sudah sangat terkenal sampai ke Kota Medan, setiap pembeli Ikan Mas mengetahui kualitas Ikan Mas yang berasal dari Daerah haranggaol serta memiliki harga yang relatif tinggi (di atas rata-rata harga Ikan Mas dari daerah lainnya), namun produksi ikan tersebut dapat dikembangkan lagi dari nilai ekonomis jika dioleh dalam bentuk lain seperti pengolahan ikan menjadi Nugget ikan yang masih jarang dilakukan oleh masyarakat setempat.

Berdasarkan data citra satelit Spot VII pada 2016, terdapat sekitar 11.282 KJA di Danau Toba. Jumlah ini tersebar pada tujuh kabupaten, $80 \%$ di Haranggaol, Kabupaten Simalungun, sebanyak 7.700 dengan kepadatan tinggi sekitar $1.000 \mathrm{KJA}$ per $300 \times 300$ meter. (Arumyngtias, 2018). 
Tabel 1.1. Banyaknya Rumah Tangga Perikanan, Luas, Produksi Dan Nilai Penjualan Petani Jaringan Apung Dan Keramba

\begin{tabular}{|l|l|l|l|l|}
\hline Kecamatan & Jumlah & $\begin{array}{l}\text { Luas } \\
\text { (Kantong) }\end{array}$ & Produksi & $\begin{array}{l}\text { Nilai } \\
\text { Penjualan }\end{array}$ \\
\hline $\begin{array}{l}\text { Pematang } \\
\text { Silimahuta }\end{array}$ & 1 & 6 & 3.6 & 59 \\
\hline $\begin{array}{l}\text { Haranggaol } \\
\text { Horison }\end{array}$ & 280 & 2.911 & $3.964,7$ & 64.941 \\
\hline $\begin{array}{l}\text { Dolok } \\
\text { Pardamean }\end{array}$ & 47 & 190 & 158,8 & 2.601 \\
\hline $\begin{array}{l}\text { Pematang } \\
\text { Sidamanik }\end{array}$ & 36 & 159 & 144,6 & 21.202 \\
\hline $\begin{array}{l}\text { Girsang } \\
\text { Sipangan }\end{array}$ & 94 & 854 & $1.294,6$ & - \\
\hline $\begin{array}{l}\text { Kabupaten } \\
\text { Simalungun }\end{array}$ & 458 & 4.12 & 5.562 .5 & 88.803 \\
\hline
\end{tabular}

Sumber: Dinas Perikanan dan Peternakan Kabupaten Simalungun 2012

Berdasarkan data di atas potensi perikanan paling besar berada di Kecamatan Haranggaol Horison. Kelurahan Haranggaol sendiri memiliki potensi perikanan keramba paling besar di Kecamatan Haranggaol Horison. Dengan demikian potensi besar untuk membuat nugget ikan dengan mengolah hasil ikan sortiran yang tidak dijual ke luar Kelurahan Haranggaol Horison sangat besar.

Waktu luang yang dimiliki kelompok wirid mamak-mamak (pengajian ibu-ibu) dapat diberdayakan dengan mengolah ikan menjadi nugget ikan dipasarkan ke daerah lainnya. Tentunya masyarakat luas tidak akan sulit menerima kualitas ikan dari nugget ikan yang dihasilkan dari Kelurahan Haranggaol. Potensi dan peluang usaha tersebut dapat memberdayakan kelompok wirid mamak-mamak (pengajian ibu-ibu) serta diharapkan dapat meningkatkan nilai jual produksi dan meningkatkan ekonomi keluarga kelompok kelompok wirid mamak-mamak (pengajian ibu-ibu) di Kelurahan Haranggaol.

Pendekatan Pelaksanaan proses dan pencapaian tujuan pemberdayaan di atas dicapai melalui penerapan pendekatan pemberdayaan yang dapat disingkat menjadi 5P, yaitu: pemungkinan, penguatan, perlindungan, penyokongan, dan pemeliharaan.

Prinsip Pelaksanaan pendekatan di atas, berpijak pada pedoman dan prinsip pekerjaan sosial. Menurut Edi Suharto, terdapat beberapa prinsip pemberdayaan menurut perspektif pekerjaan sosial:

1. Pemberdayaan adalah proses kolaboratif. Karenanya pekerjaan sosial dan masyarakat harus bekerja sama dengan partner.

2. Proses pemberdayaan menempatkan masyarakat sebagai aktor atau subjek yang kompeten dan mampu menjangkau sumber-sumber dan kesempatan- kesempatan.

3. Masyarakat harus melihat diri mereka sendiri sebagai agen penting yang dapat mempengaruhi perubahan.

4. Kompetensi diperoleh atau dipertajam melalui pengalaman hidup, khususnya pengalaman yang memberikan perasaan mampu pada masyarakat.

5. Solusi-solusi yang berasal dari situasi khusus, harus beragam dan menghargai keberagaman yang berasal dari faktor-faktor yang berbeda pada situasi masalah tersebut. 
6. Jaringan-jaringan sosial informal merupakan sumber dukungan yang penting bagi penurunan ketegangan dan meningkatkan kompetensi serta kemampuan mengendalikan seseorang.

7. Masyarakat harus berpartisipasi dalam pemberdayaan mereka sendiri.

8. Tingkat kesadaran merupakan kunci dalam pemberdayaan karena pengetahuan dapat memobilisasi tindakan bagi perubahan.

9. Pemberdayaan melibatkan akses terhadap sumber-sumber dan kemampuan untuk menggunakan sumber-sumber tersebut secara efektif.

10. Proses pemberdayaan bersifat dinamis, sinergis, berubah terus, evolutif, sedangkan permasalahan selalu memiliki beragam solusi.Pemberdayaan dicapai melalui struktur-struktur personal dan pembangunan ekonomi secara pararel.

\section{METODE PELAKSANAAN}

Setelah melakukan assesment, dan observasi terhadap potensi ikan berlimpah di Kelurahan Haranggaol dan peluang usaha pengolahan nugget ikan melalui pemasaran tradisional dan juga media sosial yang cukup tinggi serta keaktifan kelompok wirid mamak-mamak (pengajian ibu-ibu) di Kelurahan Haranggaol Kecmatan Haranggaol Horison Kabupaten Simalungun. Maka tim pelaksana pengabdian melakukan sosialisasi tentang pengolahan nugget ikan serta membeli peralatan pendukung.

Tim peneliti yang beranggotakan 3 orang salah satunya memiliki keahlian dibidang tata boga yang memiliki pengalaman dan keahlian dalam mengelola makanan terutama mengolah ikan menjadi nugget ikan. Dengan demikian, pengetahuan tentang pengolahan iken menjadi nugget ikan yang baik dan benar dapat dimiliki kelompok wirid mamak-mamak (pengajian ibu-ibu) di Kelurahan Haranggaol Kecmatan Haranggaol Horison Kabupaten Simalungun.

Packaging dan marketing produk dilakukan dengan cara menambah pengetahuan kelompok wirid mamak-mamak (pengajian ibu-ibu) di Kelurahan Haranggaol Kecmatan Haranggaol Horison Kabupaten Simalungun tentang cara membuat kemasan yang menarik serta aktif menggunakan media sosial untuk menjual produk-produk nugeet hasil olahan ikan selain juga menjual secara langsung door to dorr dan di pasar tradisional di Kelurahan Haranggaol Kecamatan Haranggaol Horison Kabuipaten Simalungun.

\section{HASIL DAN PEMBAHASAN}

\subsection{Kondisi sebelum dilaksanakan Pengabdian KKN-PPM}

Berdasarkan hasil assesemnt, observasi, diskusi, wawancara, dengan aparatur Kelurahan Haranggaol dan juga masyarakat di Kelurahan Haranggaol, khususnya kelompok wirid mamakmamak (pengajian ibu-ibu) di Kelurahan Haranggaol Kecmatan Haranggaol Horison Kabupaten Simalungun. Potensi ikan yang melimpah dengna kualitas baik (sisa sortiran yang tidak dijual luar daerah) dan harga yang miring merupakan susatu potensi di Kelurahan Haranggaol. Hal tersebut dapat dimanfaatkan dengan mengolh potensi ikan berlebih yang harganya murah dengan mengolah ikan menjadi nugget ikan. 


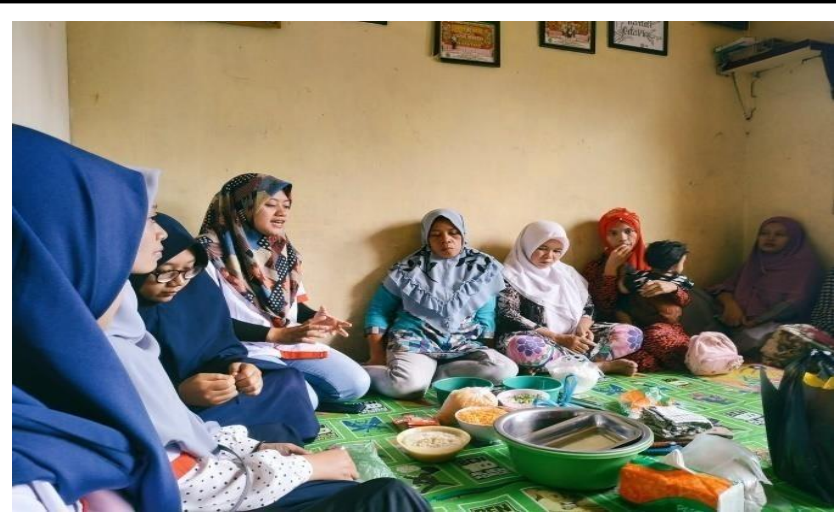

Gambar 3.1 Penyuluhan Pengolahan Nugget Ikan

Pemberdayaan masyarakat dilakukan dengan memiliki kelompok yang aktif dan solid, diketahui terdapat kelompok wirid mamak-mamak (pengajian ibu- ibu) di Kelurahan Haranggaol Kecmatan Haranggaol Horison Kabupaten Simalungun, yang aktif melakukan kegiatan keagamaan sepert membaca Yasin dan silahturahmi, kegiatan tersebut bisa dimaksimalkan dengan memberdayakan waktu luang mereka dengan mengolah nugget ikan dan memasarkannya melaui pasar konvensional dan media sosial.

\subsection{Kondisi Setelah dilaksanakan Kegiatan Pengabdian KKN-PPM}

Potensi ikan yang yang berlebih dengan harga murah dapat dimanfaatkan dengan cara diolah menjadi nugget ikan. Hasil dari penjualan ikan tersebut dipergunakan kelompok wirid mamakmamak (pengajian ibu-ibu) di Kelurahan Haranggaol Kecmatan Haranggaol Horison Kabupaten Simalungun sebagai biaya operasional, tabungan kelompok dan menambah pendapatan ekonomi keluarga.

Rasa kekeluargaan dan keharmonisan di dalam kelompok semakin tinggi. kelompok wirid mamak-mamak (pengajian ibu-ibu) di Kelurahan Haranggaol Kecmatan Haranggaol Horison Kabupaten Simalungun merasa kegiatan yang dilakukan tidak hanya menghabiskan waktu (mengisi waktu luang) tetapi juga dapat menambah penghasilan dan menguatkan solidaritas kekeluargaan diantara sesama anggota kelompok.

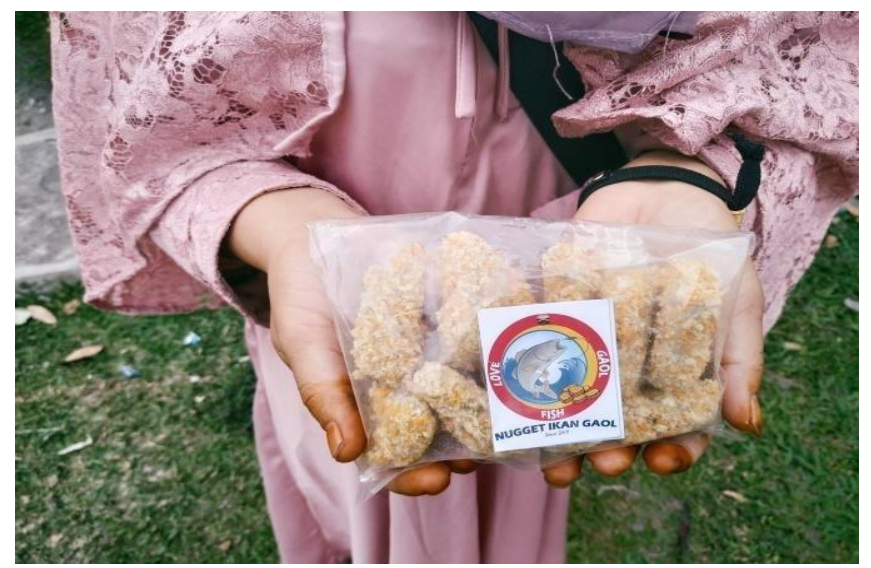

Gambar 3.2 Hasil pengolahan Nugget Ikan 


\section{KESIMPULAN}

Telah dilaksanakan sosialisasi kegiatan pengabdian yaitu pemberdayaan kelompok Wirid mamakmamak tentang pengolahan nugget ikan dalam memanfaatkan potensi ikan yang berdampak pada penigkatan ekonomi

\section{UCAPAN TERIMA KASIH}

Tim pengabdian pada masyarakat mengucapkan terima kasih kepada pihak LPPM USU yang telah memberikan dana kepada pengabdian ini. Terima kasih juga kepada pihak mitra yang telah koopratif di dalam pelaksanaan pengabdian ini.

\section{DAFTAR PUSTAKA}

Adi, Isbandi Rukminto. (2013). Kesejahteraan Sosial (Pekerjaan Sosial, Pembangunan Sosial, dan Kajian Pembangunan). Jakarta: Rajawali Pers.

Adi, Isbandi Rukminto. (2008). Intervensi Komunitas Pengembangan Masyarakat Sebagai Upaya Pemberdayaan Masyarakat. Jakarta: Raja Grafindo.

Suharto, E., (2010). Membangun Masyarakat Memberdayakan Rakyat: Kajian Strategis Pembangunan Kesejahteraan Sosial dan Pekerjaan Sosial. Bandung: PT. Refika Adi 